\title{
A Child with Acute Lymphoblastic Leukemia (ALL) Presenting with Symptomatic Hypercalcemia and Multiple Osteolytic Lesions
}

Sir,

Pediatric and adolescent ALL cases presenting with extensive lytic bony lesions with or without hypercalcemia are anecdotal and hence may prove baffling to the investigating physicians and diagnosis may be delayed, especially when there are no blasts in the peripheral blood film. However, presence of unexplained anemia and hypercalcemic symptoms can be warning clues to an astute clinician. Description and short course of one such case is presented.

A 5 years male child presented to the department of Pediatrics with complaints of anorexia, abdominal pain, constipation, polyuria, polydipsia, bony aches and pains of 2 months duration. In addition, there was history of fever, irritability, nausea and vomiting. The child was initially managed at maternity and childhealth service and later, shifted to our ward for evaluation of anemia.On examination, he was sick looking, conscious and well-oriented, febrile and pale. Bilateral cervical lymph nodes were enlarged multiple, about $1 \mathrm{x} 1 \mathrm{~cm}$. Bones were tender and bilateral hip joint movements were painful and restricted. Rest of systemic examination was within normal limits. Investigations $\mathrm{Hb} 7.7 \mathrm{~g} / \mathrm{dl}$, WBC; $6700 / \mathrm{cmm}$. ESR $30 \mathrm{~mm} / \mathrm{hr}$, differential No blasts. Platelets$268 / \mathrm{cmm}$. Liver and renal function tests were normal. Serum uric acid $10.6 \mathrm{mg} \%$. LDH 1330 i. $\mathrm{u} / \mathrm{l}$. Serial serum calcium and phosphorus readings were $-17.84,13.0,11.26 \mathrm{mgms} / \mathrm{dl}$ and $4.9,4.9,4.02 \mathrm{mg} / \mathrm{dl}$, respectively. 24 hour urinary calcium was $630 \mathrm{mgms}$ (normal upto $300 \mathrm{mg}$ / day). Electrocardiogram, cerebrospinal fluid and urine analysis were within normal limits. chest $\mathrm{x}$-ray showed normal lung fields, x-ray skull and pelvis revealed diffuse lytic lesions.
Abdominal USG scan normal.Plasma PTH - 3 $\mathrm{pg} / \mathrm{ml}(\mathrm{n}, 10-69 \mathrm{pg} / \mathrm{ml})$. In view of low $\mathrm{Hb}$, raised $\mathrm{Ca}^{++}$, lytic lesion and low $\mathrm{PTH}$, a hematological disorder was considered. Bone marrow aspiration showed $44 \%$ blasts. Blasts were PAS + ve, SB/MPO - negative and were positive for CD3, CD20 and CD45- $44.46 \%$. A diagnosis of ALL-L2 was made. Patient was started on UKALL-12 protocol and on subsequent follow up, patient was asymptomatic, bone pain had relieved, lytic lesions regressed, and remission was induced. Hypercalcemia, uric acid and serum lactic dehydrogenase levels normalized.

\section{COMMENTS:}

Bone involvement is common in ALL. About one third patients present with bone pains and approximately one-half of these have bone involvement. ${ }^{1,2}$ Presence of frank osteolytic lesions with hypercalcemia is infrequent. ${ }^{3}$ Bone destruction may be the cause of hypercalcemia besides other factors. Bony lytic lesions with accompanying hypercalcemia can develop at the onset. ${ }^{5}$ The hypercalcemia in pediatric ALL patients with early pre-B cell was estimated to be about $4.8 \%$ in a series of 83 cases from Japan with PTHrP levels lever elevated to $112-240 \mathrm{pmol} / 1$ (normal range is 17.61.2 pmol/1) in all. ${ }^{3}$ Normalization of both Increased plasma prostaglandin $\mathrm{E}_{2}\left(\mathrm{PGE}_{2}\right)$ levels (130 ng 1) and hypercalcemia can occur after chemotherapy ${ }^{6}$ Presentations as in our case have also been reported in adult $\mathrm{T}$ cell leukemia ${ }^{7}$ as well as in adult $\mathrm{T}$ cell leukemia/lymphoma. ${ }^{8,9} \mathrm{In}$ the latter, it may be associated with elevated levels of interleukin-6 and PTHrP. ${ }^{7}$ Hypercalcemia in cancer can be due to release of tumour necrosis factor (alpha and beta), IL1, 2, 6, TGF beta, 1, 25(OH) 2 and direct invasion, 
apart from excess of PTHrP ${ }^{10}$ and PGE2 and rarely due to PTH secretion. The later may be secreted directly by the lymphoblasts. Frequently, blasts are absent from the peripheral blood in such cases. ${ }^{4,7,2}$ A single patient of acute megakaryocytic leukemia (M7) presenting with hypercalcemia and skeletal lytic lesions has also been described. ${ }^{13}$ The final outcome of children with hypercalcemia is similar to children with ALL indicating that the development of hypercalcemia itself is not a poor prognostic factor. ${ }^{14}$ Curiously such manifestations, have rarely been reported in CML, CLL in adults. Apart from treatment of the basic disease, hypercalcemia needs to be addressed with measure like saline diuresis, calcitonin and bisphosphonates.

Intriguely, apart from anemia peripheral blood counts were maintained in this patient also and he presented chiefly with clinical features of hypercalcemia at the onset and had a delay in diagnosis. Hence, in a child presenting with a short illness with hypercalcemia and anemia, ALL should be included the list of differential diagnosis. Furthermore, rising serum calcium levels after normalization could herald a leukemia relapse in such a case...

\section{REFERENCES :}

(1) Nies BA, Kundal DW, Thomas LB et. al. Leucopenia bone pain, bone necrosis in patients with acute leukemia. A clinicopathological complex. Ann Intern Med 1965;62:698,92.

(2) Osteopenia or lytic lesions may be seen in upto 50\% of patients in ALL Randy B. Hanna $k$ in Leukemia in Washington Manual of Oncology, 2002 Page 253;

(3) Hibi S. Funaki H, Oschiai-Kanai et. al. Acutelymphoblastic leukemia in adolescence with multiple osteolytic lesions and hypercacemia mediated by lymphoblast producing parathyroid hormone related peptide: a case report and review of literature Pediatr Blood Cancer 2005;45[3]333-9.

(4) Shimon Dan H, Nagoya J, Negates Y, et. al. Acute lymphocyte leukemia in adolescence with multiple osteolytic lesions and hypercalcemia mediated by lymphoblast-producing parathyroid hormone-related peptide: a case report and review of the literature. Pediatr Blood Cancer, 2005:45(3),333-9.

(5) Paola B, Antonio R, Marco P, Riccardo R, Giancario p, Antonio C.A case of acute lymphblastic leukemia prsesenting as severe hypercalcamia. Pediatric Hematology and Oncology, 2004;Vol. 21,(6)475-479.

(6) Shinjiro Todo, Shinsaku Imashuku, Hiroshi Inoda,et al. Hypercalcemia in a Case of Childhood Acute Lymphoblastic Leukemia, Japanese J. Clin Oncol 1987:17:357-362.

(7) Antunovic P, Marisavljevic D, Kraguljac N, Jelusic $V$. Severe hypercalcaemia and extensive osteolytic lesions in an adult patient with $T$ cell acute lymphoblastic leukaemia. Med Oncol, 1998;15(1):5860.

(8) Yamamoto $Y$, Ishii K, Nomura $S$, Fukuhara $S$. Adult T-cell leukemia /lymphoma of bone with multiple pathological fractures] Rinsho Ketsueki. 2004;45(3):247-9.

(9) Anzai S, Takayasu S, Fujiwara S, Tateyama M, Taira $H$. Takashita M. Elevation of IL-6 in ATL patient with a pathological fracture. $J$ Dermatol. 2002;29(10):644.

(10) Miyamura T, Taguchi F, Ishikura H, et al. Production of parathyroid hormone-related peptide in a patient with acute lymphocytic leukemia with extensive osteolytic lesions and hypercalcemia. Am J Hematol. 1995;50(2):150-1.

(11) Lankisch P, Kramm CM, Hermsen D, Wessalowski R. Hypercalcemia with nephrocalcinosis and impaired renal function due to increased Parathyroid hormone secretion at onset of childhood acute lymphoblastic leukemia. Leuk Lymphoma. 2004;45(8):1695-7.

(12) Shanks D, Linke R, Saxon B. Bones groans and blasts. $J$ Paediatr Child Health. 2001;37(5):504-6.

(13) Muller JH, Valdez $R$, Hayes $C$, and Kaminski $M S$, Acute megakaryocytic leukemia presenting as hypercalcemia and osteolytic lesions.Eur $J$ Haematology. 2002;68(6):392-6.

(14) T Inukai, K Hirose, T Inaba et al, Hypercalcemia in childhood acute lymphoblastic leukemia: frequent implication of parathyroid hormone-related peptide and E2A-HLF from translocation 17:19 Leukemia 2007;21,288-296.

Gull Mohd. Bhat, Department of Medical Oncology Sher-i-Kashmir Institute of Medical Sciences (SKIMS) E-mail:drgull8125@yahoo.com 